\title{
Grammaticalization in Tok Pisin
}

\section{Cindy Tung}

\section{WHAT IS TOK PISIN?}

Tok Pisin began as an English-based pidgin spoken by the majority of Papua New Guinea's population, with many of these people speaking Tok Pisin as a L $2^{1}$, but the language is now classified as a creole. It is hard to pinpoint the exact definitions of the words "pidgin" and "creole," as both are contact languages that are created out of circumstances where people cannot dialogue with their existing languages. The definition of a pidgin is "a system of communication which has grown up among people who do not share a common language [but desire communication]" (Crystal 2010: 344), and the primary distinction between a creole and a pidgin is that a creole is spoken as a native language and pidgins are only spoken as an L2. Pidgins also tend to be limited in scope, covering only a limited topic, often trade. As a language evolves from a pidgin to a creole, the vocabulary expands to cover more aspects of communication.

Tok Pisin traces its history to the pidgin of Samoan plantations located roughly 2,500 miles west of Papua New Guinea. Under German plantation owners and colonial masters, native English input was unavailable, and vocabulary was incorporated into Tok Pisin by a strategy of its own, causing Tok Pisin to develop as a language without heavy English influence (Mühlhausler 2003: 5). Although the majority of the lexicon originates from English, German words were adopted into Tok Pisin during Germany's rule of Papua New Guinea. Some of these words include beten 'to pray', raus 'get lost', and borim 'to drill' (Mühlhausler 2003: 27). There are also influences from the native Papua New Guinean language of Kuanua, spoken by the Tolai people: lapun 'old', kumu 'bird of paradise'; as well as influence from other languages used by visitors, such as Malay ${ }^{2}$ and Portuguese ${ }^{3}$ (Tung 2013).

Starting in the 1900s, the government overseeing Papua New Guinea used Tok Pisin as a lingua franca for trade, paying translators to communicate between the government and the villages; natives equated the knowledge of Tok Pisin with wealth and access to resources (Mühlhausler 2003: 6). Since then, the status and prestige of Tok Pisin has decreased with the growth of English, but Tok Pisin is still used by the majority of the population when speaking to people outside of their Tok Ples, the language of their village. Because people are beginning to move from villages into cities, there is a new generation of native Tok Pisin speakers, which firmly establishes Tok Pisin's status as a creole and not a pidgin.

\section{WHAT IS GRAMMATICALIZATION?}

Grammaticalization is "a process of language change by which a free lexical morpheme becomes semantically generalized and phonologically reduced” (Whaley 1997: 285). Joan Bybee lists four characteristics of the grammaticalization process including: phonetic reduction, generalized and abstract meanings, an increase in frequency of use, and a gradual change in both form and function of the word. This process occurs in all languages. However, in pidgins and creoles, the process is easier to observe because these languages change at a much higher speed

\footnotetext{
${ }^{1}$ L2 stands for any language beyond one's native language, including second, third, fourth languages, etc.

2 Malay words include palai 'lizard' or 'gecko', binatang 'insect', and lombo 'chili pepper'.

${ }^{3}$ Portuguese words include pikinini for 'child' and save meaning 'to know'.
} 
and the words grammaticalized often originate from the superstrate ${ }^{4}$ language. It is important to note that because pidgins and creoles change so rapidly, the grammatical function of words cannot always be classified precisely, as it is likely still shifting.

Tok Pisin is an English-based creole and therefore the English meanings and grammatical constructions of the borrowed words are available for an investigation of instances of grammaticalization and can help to identify patterns and trends of grammaticalized words in Tok Pisin.

\section{A STANDARD CASE OF GRAMMATICALIZATION: THE WORD BILONG}

The prototypical case of grammaticalization in Tok Pisin is the suffix -pela, which originated from the word "fellow" in English and the suffix has developed into a plural marker and a general adjective marker (Roberts 2008: 2, Goulden 1989). Since the case for grammaticalization of "fellow" into - pela has already been established in prior literature, this next section will look at the word bilong, another instance of well-established grammaticalization in Tok Pisin, analyzing how the word has been incorporated using the characteristics of the grammaticalization process outlined by Bybee.

The first component of the grammaticalization process is phonetic reduction. Bilong comes from English "belong"; the shift does not seem to exhibit much phonetic change. However, in the speech of certain areas of Papua New Guinea, speakers are starting to drop the /i/ in conversations, pronouncing the word b'long.

A second grammaticalization feature is the abstraction or broadening of meaning. Initially, bilong was used in Tok Pisin as a possessive marker, similar to the English word 'belong'. The following sentence uses bilong similarly to how it can be used in English to say "The man who belongs to her is in the house" where semantically "the man who belongs" to her means 'her husband'.

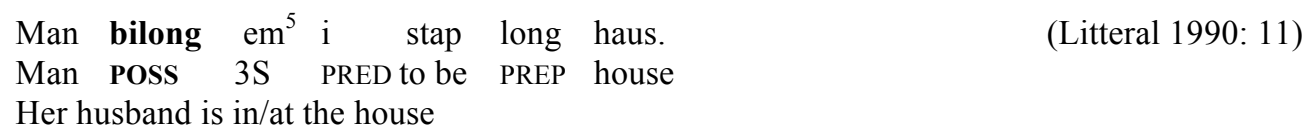

Gradually, the word bilong expanded into being a general attributive marker as shown in the example below.

$\begin{array}{lllll}\text { Em i meri } & \text { bilong } & \text { toktok } & \text { (Litteral 1990: 54) } \\ \text { 3S PRED woman } & \text { POss } & \text { gossip } & \\ \text { She is a gossip } & & \end{array}$

This construction can be used in a wide range of attributions - a man bilong wok means 'a hardworking man' - a clear expansion of meaning from the semantically narrower English "belong." The use of bilong in this sense is actually quite similar to the English "of," which also has an abstract definition. In turn, this causes the frequency of use to increase because the definition has expanded and can therefore cover more contexts. These gradual shifts in bilong are similar to many other English words that have been grammaticalized and integrated into Tok Pisin syntax.

\footnotetext{
${ }^{4}$ Pidgins and creoles are influenced by both superstrate and substrate languages. English is the Tok Pisin's superstrate, the language influencing pidgin or creole development with higher power and prestige. Substrate languages are commonly viewed as less prestigious, in this case referring to the indigenous languages of Papua New Guinea.

${ }^{5}$ While the third person singular pronoun $\mathrm{em}$ in Tok Pisin does not express gender, one can conclude from the example that, in this sentence, em stands for 'her' and not 'his'.
} 
TENSE

Tense in Tok Pisin is marked with grammaticalized particles. As with most pidgins and creoles, Tok Pisin does not have a large number of inflectional morphemes for case or agreement. Instead, pidgins and creoles use adverbial expressions and particles to show tense (Romaine 1990: 192). The two tense markers primarily used in colloquial Tok Pisin currently are bai and pinis, marking the future and past tenses, respectively. There is a second particle to indicate past tense, bin, but modern speakers seem to favor pinis over bin to mark the past. Bai comes from the English idiom "by and by," which initially grammaticalized as baimbai. Bai is placed at the beginning of the clause to mark the future tense or irrealis case.

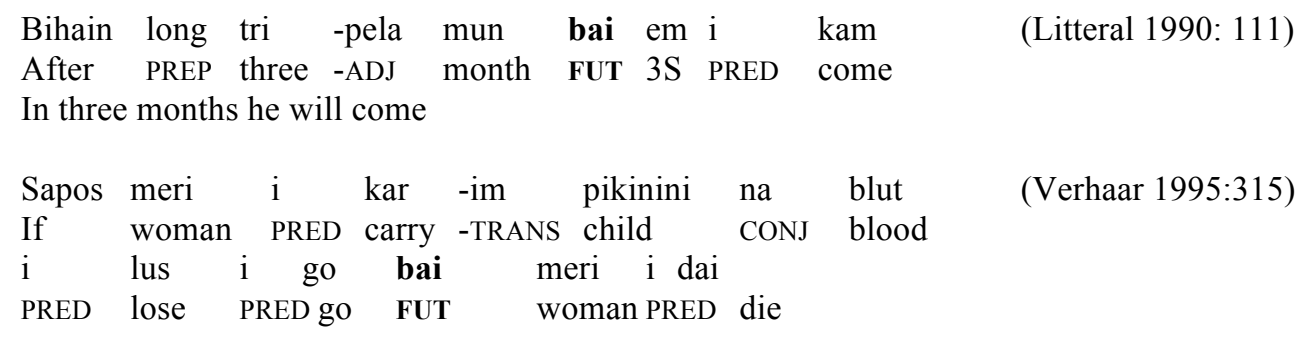

If a woman carrying a child (in childbirth) keeps hemorrhaging, the woman will die

Pinis was grammaticalized from English "finish" to indicate the past tense. It is usually at the end of the sentence but can also be found directly after the verb in some circumstances.

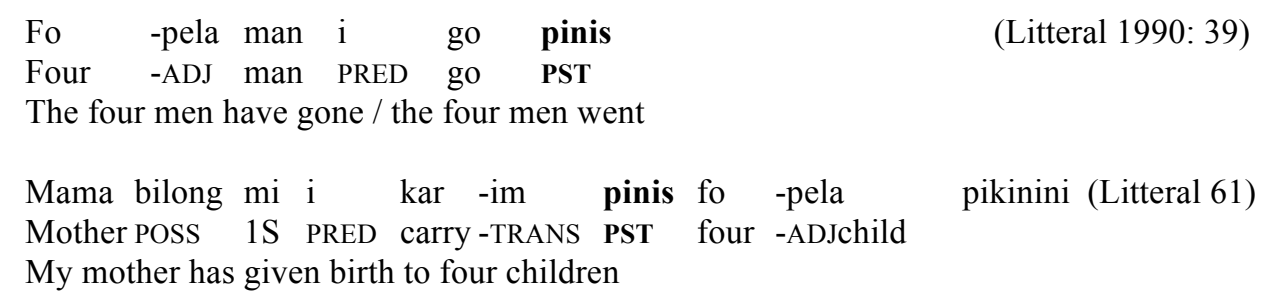

More than just the past tense, pinis has a perfective implication as well. Mi save expresses the equivalent of English's 'I know'. However, to indicate that one has entirely understood, one would add pinis, as shown below.

$\begin{array}{lcc}\text { Mi } & \text { save } & \text { pinis } \\ \text { 1S } & \text { know } & \text { PST } \\ \text { I ( } & \text { completely) } & \text { understand }\end{array}$

Both of these tense markers are grammaticalized from English, one from an idiomatic expression and the other from a verb.

\section{GRAMMATICALIZED PRONOUNS}

Two examples of grammaticalization that are more challenging to unpack are the morphemes $i$ and -im, grammaticalized from "he" and "him," respectively (Sankoff 1993: 120). The morpheme $i$ is usually glossed as a predicate ${ }^{6}$, but there is no real consensus amongst Tok Pisin speakers about its exact distribution (Mundhenk 1990: 347). Historically, it was used as a

\footnotetext{
${ }^{6}$ Predicate is defined as "the clause element that gives information about the subject" (Crystal 456)
} 
topicalizer, probably from a statement such as "John, he went to the store." Some speakers use $i$ after all subjects regardless of person and number, whereas the majority of Tok Pisin speakers use it only after third person pronouns or other nouns (Sankoff 1993: 120). To further complicate this distribution, many speakers are dropping the $i$ almost entirely (Mühlhausler 1990: 239). There is a slight difference in the meaning of the following two sentences listed below, one with the $i$ and one without. With the $i$ in the second sentence, em is more immediate than in the first sentence, but although there is a subtle change in meaning, many native speakers do not distinguish between the two sentences.

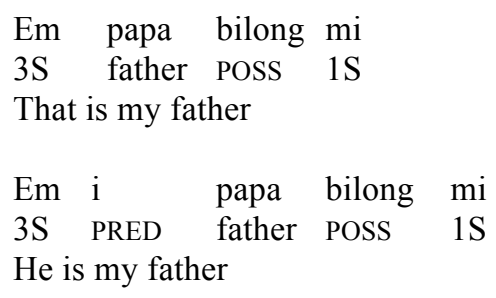

In addition, the words kam, go, and stap, in particular, require the $i$ whether it is a verb or a post verbal aspectual marker (Sankoff 1984: 114). Some speakers are starting to incorporate the $i$ as part of these words, turning them into ikam, igo, and istap instead of the predicate + verb pattern.

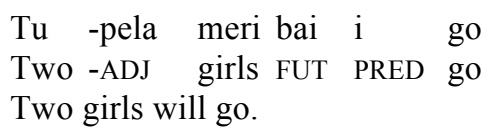

(Sankoff 1984: 115)

While the grammatical role that $i$ plays in Tok Pisin may require more contemporary research, it is clear that it is an example of grammaticalization. It was phonologically reduced from "he", has broadened and became more abstract in its meaning, and has increased in frequency of use. The word $i$ plays a different role than "he" does in English and occurs in very different distributions.

The other morpheme grammaticalized from an English pronoun is the suffix -im, which acts as a transitive marker at the end of most transitive verbs (Sankoff 1993: 120).

$\begin{array}{lllll}\text { Kis -im wara bilong drink i kam } & \text { (US Gov. 22) } \\ \text { Get -TRANS water POSS drink PRED come } & \end{array}$

However, not all transitive verbs have the -im ending. The verb kaikai 'to eat' does not take the transitive marker, perhaps because it stems from a Maori word meaning 'food' and not from English. There is a word kaikaim, but it means 'to bite'.

$$
\begin{aligned}
& \text { Mi kaikai pinis } \\
& \text { 1S eat PST } \\
& \text { I (finished) eating/ I ate } \\
& \text { Mi kaikai saksakpinis } \\
& 1 \mathrm{~S} \text { eat sago PST } \\
& \text { I (finished) eating sago/ I ate sago }
\end{aligned}
$$

The suffix -im is another example of grammaticalization. It was phonologically reduced. Furthermore, -im does not only apply to masculine nouns or singular objects; these features of 
the word "him" in English were lost in the grammaticalization process and -im was expanded to mark direct objects in sentences.

The grammaticalization of these two pronouns into Tok Pisin grammatical categories emphasizes that the process of grammaticalization "is unidirectional... [as] nouns and verbs lose their categorical status and become prepositions, auxiliaries, and other grammatical forms... [and as] [f]ree elements become more restricted and fuse with other elements" (Bybee 2003: 145). Essentially, grammaticalization takes words or units and strips them down and generalizes the meaning of the words.

\section{OTHER GENERAL TRENDS AND PATTERNS}

Trend 1: Overall, there is a tendency to grammaticalize into adverbs and adjectives.

Based on these twenty-five selected instances of grammaticalization in Tok Pisin, fourteen of these cases are grammaticalized into adverbs and adjectives (Appendix B). This is expected because pidgins and creoles typically have a limited vocabulary, and adjectives and adverbs add subtle differences to existing words in the lexicon.

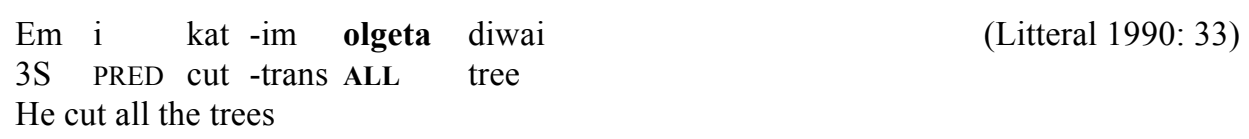

Nouns are often not marked for plural, and, above, olgeta is a way of describing that the subject cut more than one tree without overtly adding a plural affix. Olgeta comes from the expression "all together" and has retained the plural meaning, but its meaning expanded from characterizing a group to 'everything' or 'all things'. Olgeta can also be used as a pronoun as in:

$\begin{array}{llll}\text { Jisas laik } & \text {-im } & \text { olgeta } \\ \text { Jesus love } & \text {-TRANS } & \text { all } \\ \text { Jesus loves everyone } & \end{array}$

Stret originating from "straight" usually means something is correct.

Em i no wok -im stret em i wok -im kranki (Litteral 1990: 112)

3S PRED NEG make-TRANS correct 3S PRED make -TRANS wrong

He did not make it correctly, he made it incorrectly.

Below, stret adds meaning by giving validity to what is said.

Em tok stret

3S talks correct

What he said is right/true

In certain specific contexts, it could also mean directionally straight, although this would be the more marked meaning.

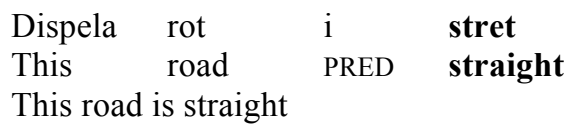


These are just two examples of grammaticalization into adverbs and adjectives, a common occurrence because adverbs and adjectives add meaning to the language without adding new nouns or verbs.

\section{Trend 2: An expansion of meaning allows grammaticalization to occur within the same functional class.}

Examples where grammaticalization happens within a functional class warrant a closer look to confirm that they are indeed cases of grammaticalization, usually through an expansion of meaning or distribution.

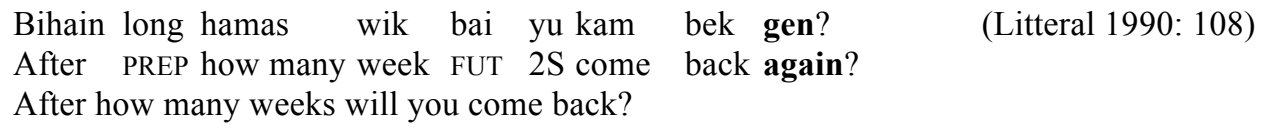

Originally, this example was in the list of grammaticalization, but after closer inspection, gen seems to only appear in contexts where "again" functions in English. There has been phonological reduction, and it is not improbable that grammaticalization can develop from the word "again". However, at this point, it does not seem like the meaning of gen has expanded beyond "again".

This is not to say that grammaticalization cannot happen within a functional class. The word tumas from the English "too much" has expanded in meaning and lost the implication of excessiveness in "too much". Colloquially this is used very often in a Tok Pisin phrase similar to English's "thanks a lot".

Tenk yu tumas
Thank $2 \mathrm{~S} \quad$ a lot
Thank you a lot/thank you verb much

Tumas can express excessiveness but only when used in conjunction with planti, meaning 'many'.

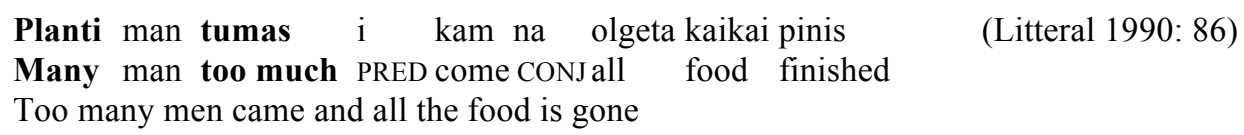

Therefore, tumas is an example of grammaticalization within the same functional class, whereas gen is not. In order to have grammaticalization, there needs to be more than just a reduction of phonemes. A change in meaning or distribution of the word is necessary as well.

\section{CURIOSITIES}

The grammaticalization of the word for woman is meri, which is curious because it comes from a proper noun, "Mary".

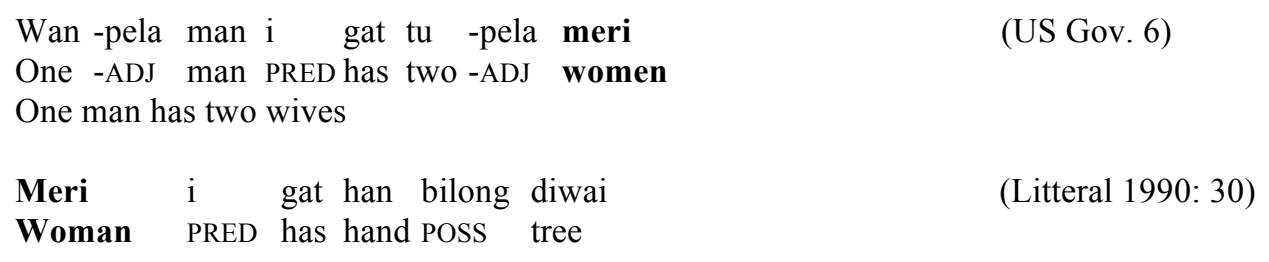


The woman has the branch of the tree

Mi gat wan -pela pikinini man na tu -pela pikinini meri

1S has one -ADJ child male and two -ADJ child female

I have one boy and two girls

This is grammaticalization because the meaning of meri has expanded far beyond a reference to a particular woman named "Mary" to refer to any woman or women and now is even used as an adjective describing anything female such as in pikinini meri meaning 'girl'. Even though it is an unusual candidate for grammaticalization, meri has been fully integrated into Tok Pisin grammar.

\section{Grammaticalization Within Tok Pisin}

As stated earlier, grammaticalization is a process that also happens within a language itself. Across languages, it is a common trend to grammaticalize the numeral "one" into an indefinite article, and this can be seen happening in Tok Pisin as well (Bybee 2003: 147). The number "one" in Tok Pisin was first grammaticalized from English. The two components wan + pela came from a phonetic adaption of English "one" and -pela, the plural and adjectival marker, reinforcing that numbers come before the nouns they modified. All Tok Pisin numbers follow this same pattern of an English number with the -pela suffix tacked on, but wanpela has expanded into an additional grammatical function.

$\begin{array}{lllll}\text { Mi bin luk } & \text {-im } & \text { wanpela } \operatorname{man} & \text { (Unilang) } \\ \text { 1S PST look } & \text { TRANS } & \text { a } & \text { man } & \\ \text { I saw a man } & & \end{array}$

In this sentence, the default translation would be "I saw a man." However, in certain contexts, it would make more sense to translate the sentences as "I saw one man."

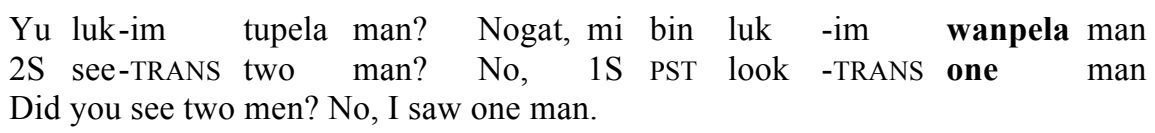

It is important to note that this second example is a marked context, and therefore the default understanding for wanpela would actually be the indefinite article over the numeral "one." This broadening of meaning and increase in abstraction makes wanpela an example of grammaticalization within Tok Pisin itself.

\section{CONCLUSION}

Pidgins and creoles are ideal languages to observe linguistic change such as grammaticalization because these languages grow and expand much faster than other more established languages do. Grammaticalization often involves the phonological reduction and adaptation of words, phrases, and sometimes even sentences. More than just a phonological change, grammaticalization also requires the word to be used in new contexts, often expanding the original meaning of the word into a more abstract definition or function. While Tok Pisin has grammaticalized many lexical words from English for grammatical functions, such as tense or plural markers, there are also examples of grammaticalization where words retain a lexical meaning, that has shifted or expanded- which case, the Tok Pisin words are used in new contexts that the English source words could not have been used in. These changes in Tok Pisin 
vocabulary have been consistent with previous explanations and claims of grammaticalization, and it will be interesting to continue tracing the past and future changes of Tok Pisin as the language becomes more established and standardized. 


\section{Appendix A}

\section{Tok Pisin Grammaticalization Chart}

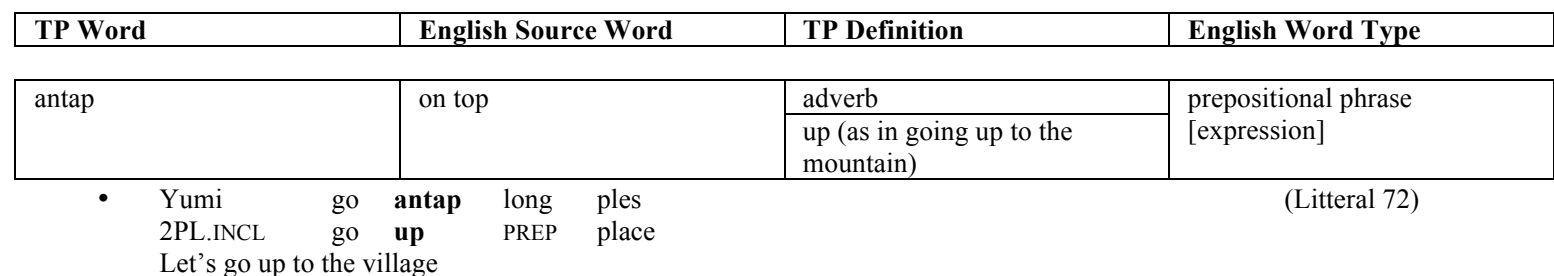

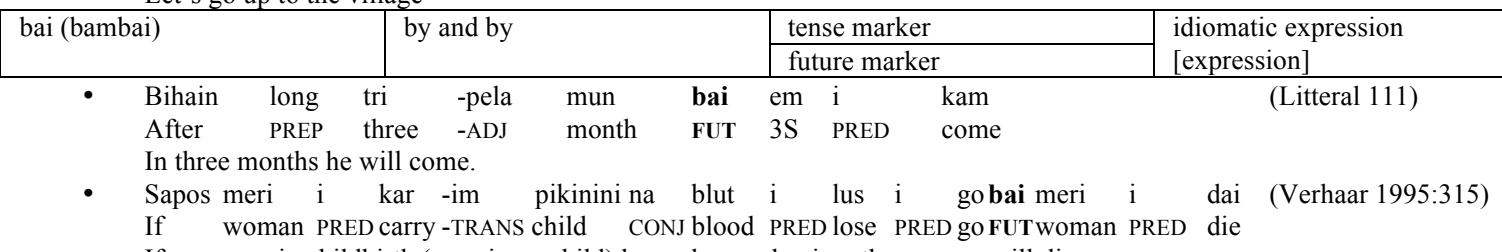

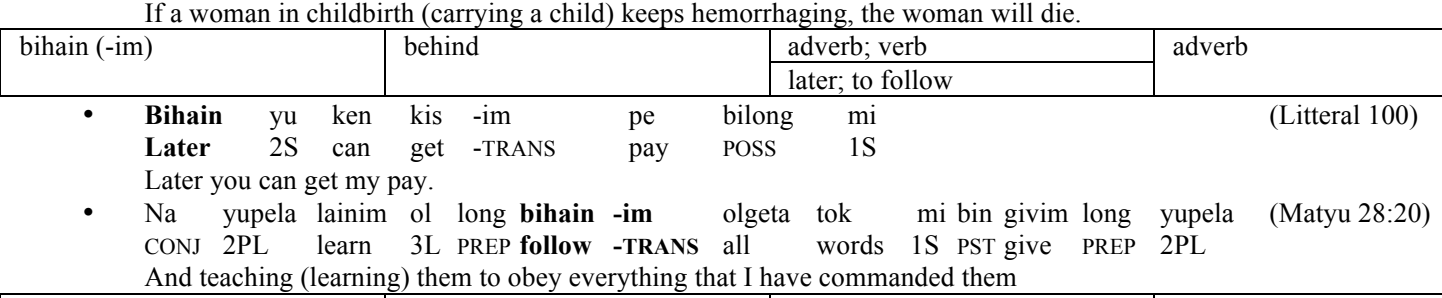

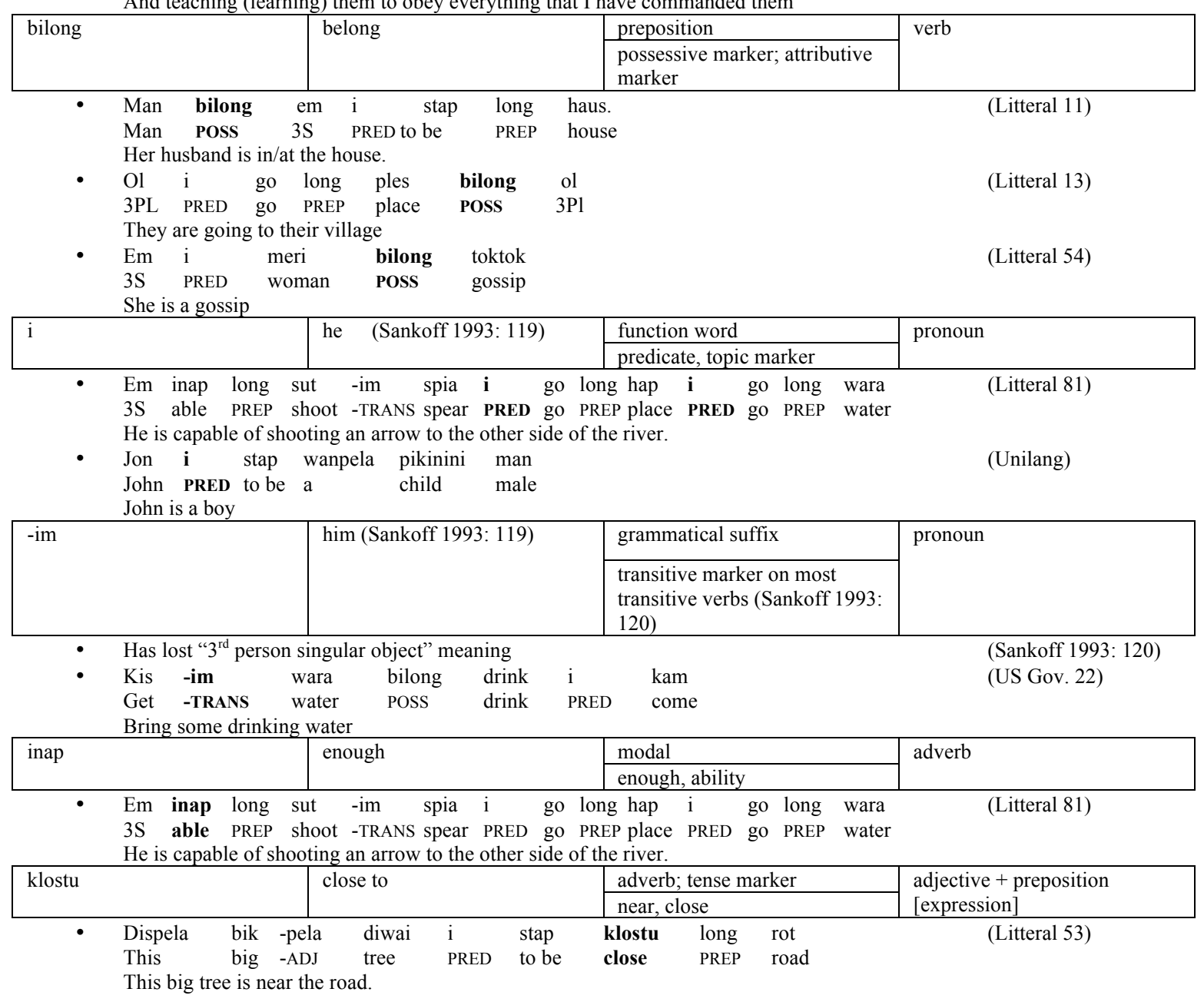




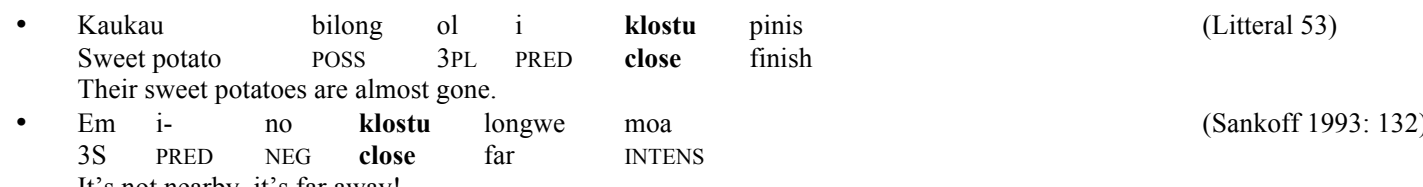
It's not nearby, it's far away!

\begin{tabular}{|l|l|l|l|}
\hline laik (-im) & like & verb & verb \\
& & like, want, need, love & \\
\hline
\end{tabular}

- $\quad$ Mi laik kar - im $\quad$ em $\mathrm{i}$ go long haus bilong yumi (Litteral 61)

1S want to carry -TRANS $3 \mathrm{~S}$ PRED go PREP house POSS 1PL.INCL

I want to carry him to our house

- Mi laik -im et -pela moa

(Litteral 76)

1S want -TRANS eight -ADJ more I want eight more

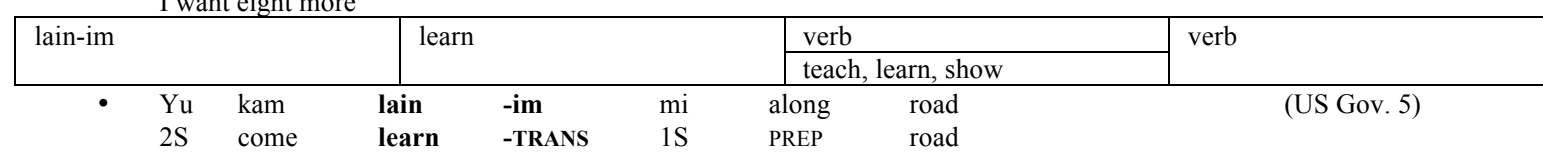

You come and show (learn) me the road

\begin{tabular}{|l|l|l|l|}
\hline long & along & preposition \\
& $\begin{array}{l}\text { preposition } \\
\text { to/from/at/in/on/etc. }\end{array}$ & \\
\hline
\end{tabular}

- $\quad$ Pik i kam long mi. Pig PRED come PREP $1 \mathrm{~S}$

The pig is coming to me.

- $\quad$ Em i kat -im diwai long wanem samting? (Litteral 27) $3 \mathrm{~S}$ PRED cut -TRANS tree PREP what thing

With what did he cut the tree?

$\begin{array}{lllllllll}\text { - } & \text { Em i go long bus long sut } & \text {-im } & \text { pik }\end{array}$

$3 \mathrm{~S}$ PRED go PREP jungle PREP shoot -TRANS pig

He is going to the jungle to shoot a pig

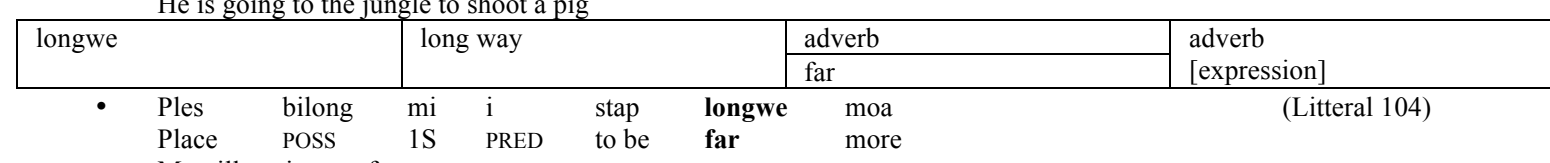

\begin{tabular}{|c|c|c|c|}
\hline \multirow[t]{2}{*}{ meri } & \multirow[t]{2}{*}{ Mary } & noun/adjective & \multirow[t]{2}{*}{ proper noun } \\
\hline & & female (as in pikinini meri) & \\
\hline
\end{tabular}

$\begin{array}{llllllll}\text { - Wan -pela } & \text { man } & \mathrm{i} & \text { gat } & \text { tu } & \text {-pela meri } & \text { (US Gov. 6) }\end{array}$

One -TRANS man PRED has two -ADJ women

One man has two wives

- Meri i gat han bilong diwai

(Litteral 30)

Woman PRED has hand POSS tree

The woman has the branch of the tree

\begin{tabular}{|l|l|l|l|}
\hline nogat & no got & negative & $\begin{array}{l}\text { sentence/verb phrase } \\
\text { [expression] }\end{array}$ \\
\cline { 3 - 4 } & & negative marker & \\
\hline
\end{tabular}

- Yupela i gat kaikai, o nogat?

2S PRED have food or NEG

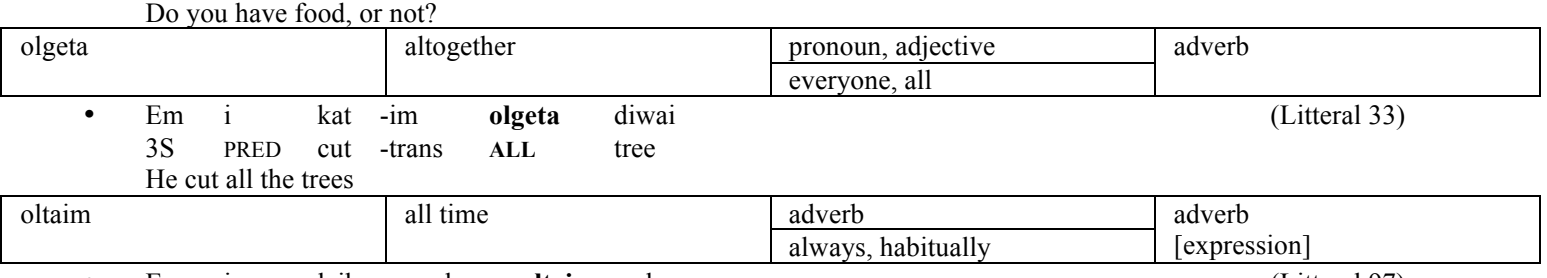

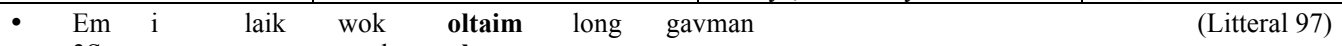

3S PRED want work always PREP government

He wants to work for the government forever

\begin{tabular}{|l|l|l|l|}
\hline -pela & fellow & grammatical suffix & noun- masculine, has \\
\cline { 3 - 4 } & & $\begin{array}{l}\text { pronoun pluralizer, general } \\
\text { classifier suffixed to } \\
\text { adjectives, quantifiers, and } \\
\text { demonstratives }\end{array}$ & \\
& & & \\
& &
\end{tabular}

- $\mathrm{Yu}$-pela $\mathrm{i} \quad$ kaikai wanem?

2 PL PRED eat what

What are you eating? 
- Susa bilong mi $\mathrm{i}$ gat bik -pela haus (Litteral 28) Sister POSS 1S PRED have big -ADJ house My sister has a big house

- $\mathrm{Mi}$ ba -im wan -pela buk long fifti toea $1 \mathrm{~S}$ buy -TRANS one -ADJ book PREP 50 toea

(Litteral 33) I bought a (one) book for 50 toea.

\begin{tabular}{|l|l|l|l|}
\hline pinis & finish & verb \\
\cline { 3 - 4 } & & $\begin{array}{l}\text { tense marker } \\
\text { finished, marks a completed } \\
\text { past tense; completed action } \\
\text { (Mühlhäusler 28) }\end{array}$ & \\
\hline
\end{tabular}

- $\quad$ Fo -pela man i go pinis Four -ADJ man PRED go PST

The four men have gone / the four men went

- Mama bilong mi i kar -im pinis fo -pela pikinini (Litteral 61) Mother POSS 1S PRED carry -TRANS PST four -ADJ child My mother has given birth to four children

- Mi pundaun na olgeta wara i $\quad$ kapsait pinis. 1S fall down CONJ all water PRED spill PST I fell down and all of the water spilled

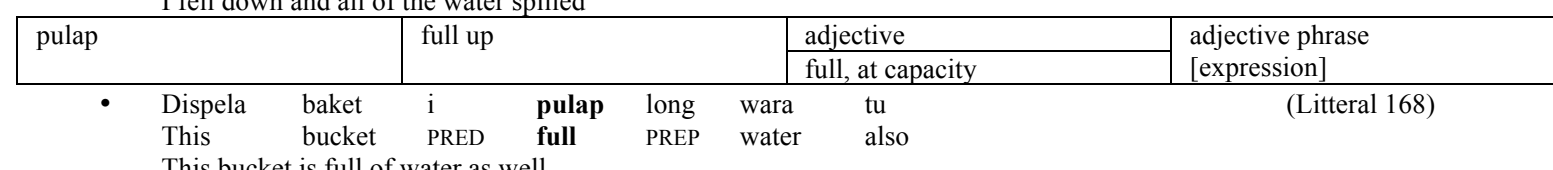

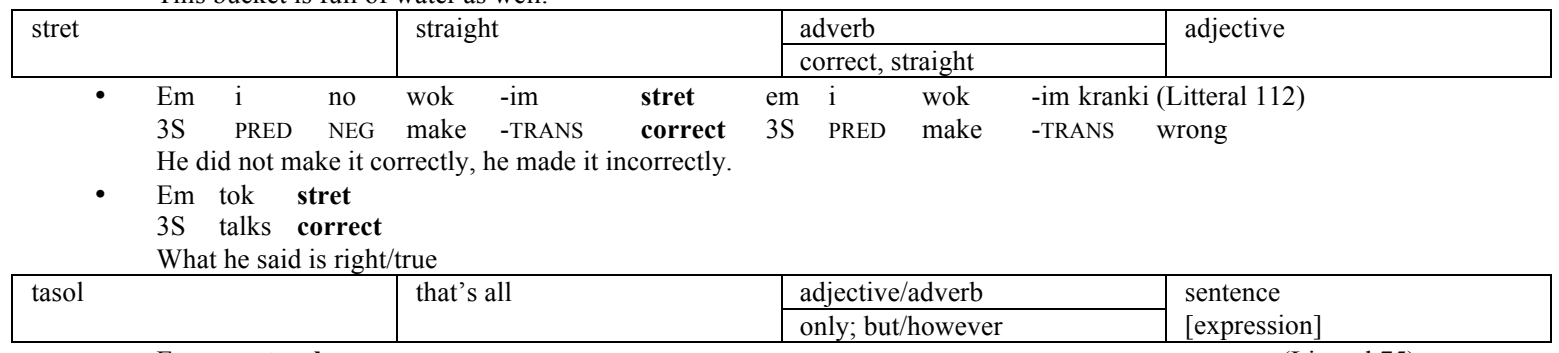

- $\quad$ Em tasol

3S only

That's all/that's it/that's all right

1S get -TRANS part tasol

(Litteral 75)

I only got part of it

come PST PREP Lae

Yesterday the plane was at Rabaul, but today it came to Lae.

- $\quad$ Em i laik slip tasol

3S PRED want sleep only

He just wants to sleep

- $\mathrm{Yu}$ dispela boi tasol $\mathrm{i}$ kam na stilim kakaruk bilong mi (Sankoff 1993:132) $2 \mathrm{~S}$ this boy INTENS PRED come CONJ steal chicken POSS $1 \mathrm{~S}$ You are that very boy who came and stole my chickens

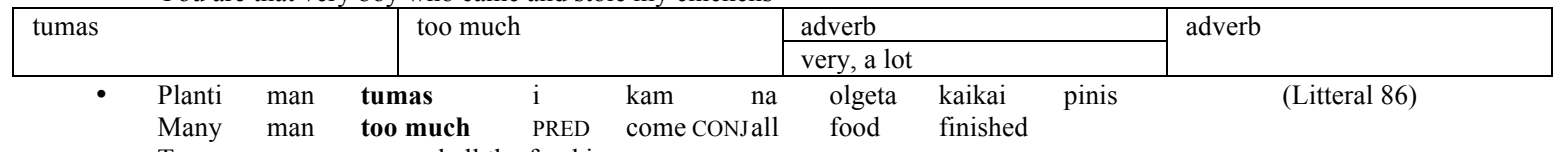

Too many men came and all the food is gone

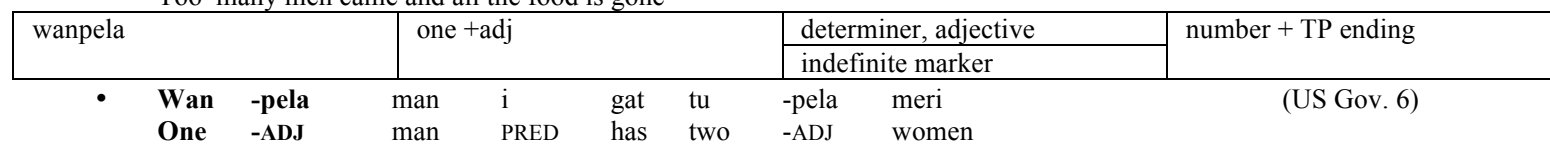

One man has two wives

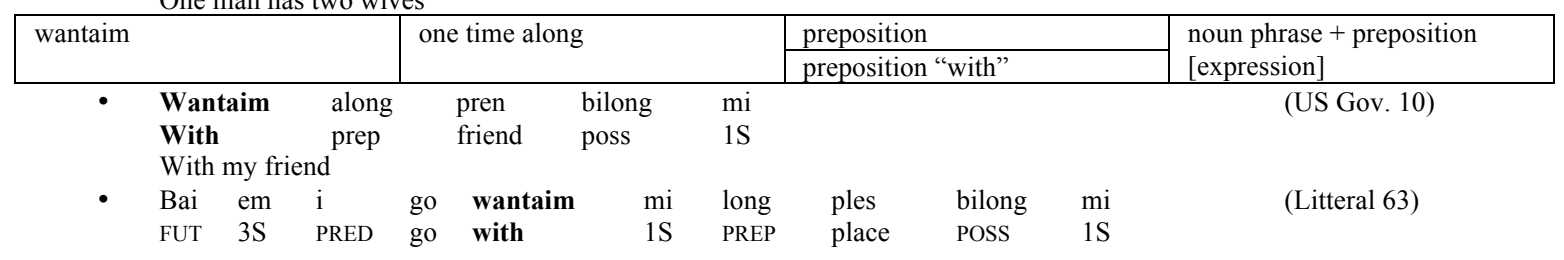


He will go with me to my village

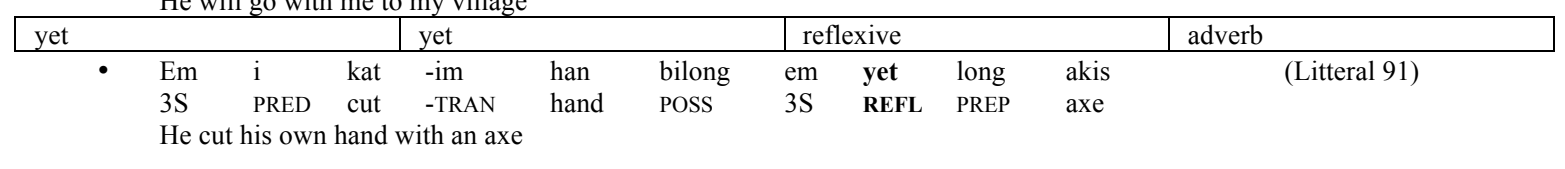




\section{ApPendix B \\ Grammaticalization Trends}

$\begin{array}{lll}\text { Adverb } & \rightarrow & \text { adverb } \\ \text { Adverb } & \rightarrow & \text { adverb/verb } \\ \text { Adverb } & \rightarrow & \text { pronoun/adjective } \\ \text { Adverb } & \rightarrow & \text { reflexive } \\ \text { Adverb } & \rightarrow & \text { modal } \\ \text { Adjective } & \rightarrow & \text { adverb } \\ \text { Adjective } & \rightarrow & \text { adjective } \\ \text { AP } & \rightarrow & \text { adjective } \\ \text { Adjective + prep } & \rightarrow & \text { adverb } \\ \text { Verb } & \rightarrow & \text { preposition } \\ \text { Verb } & \rightarrow & \text { verb } \\ \text { Verb } & \rightarrow & \text { tense marker } \\ \text { VP } & \rightarrow & \text { negative marker } \\ \text { Noun } & \rightarrow & \text { grammatical suffix } \\ \text { Proper noun } & \rightarrow & \text { noun/adjective } \\ \text { Pronoun } & \rightarrow & \text { function word } \\ \text { Pronoun } & \rightarrow & \text { grammatical suffix } \\ \text { NP + prep } & \rightarrow & \text { preposition } \\ \text { Preposition } & \rightarrow & \text { preposition } \\ \text { PP } & \rightarrow & \text { adverb } \\ \text { Idiomatic expression } & \rightarrow & \text { tense marker } \\ \text { Sentence } & \rightarrow & \text { adjective/adverb }\end{array}$




\section{APPENDIX C \\ Tok Pisin Grammaticalization Chart (Removals)}

Phonological reduction, no expansion in meaning:

\begin{tabular}{|cl|l|l|l|}
\hline gen & again & adverb & adverb \\
\cline { 4 - 5 } & & repeat & (Litteral 108) \\
\hline & Bihain long hamas wik bai yu kam bek gen? & \\
After PREP how many week FUT 2S come back again? &
\end{tabular}

Meaning has only slightly expanded:

\begin{tabular}{|ll|l|l|l|}
\hline isi & & easy & adverb & adjective \\
\cline { 3 - 4 } & & slow & \\
\\
\end{tabular}

- Planti man i stap long ples

Many man PRED to be PREP place

(Litteral 35)

There are a lot of men in the village.

- Em i save planti samting

3S PRED know many things

(Litteral 40)

He knows about a lot of things 


\section{REFERENCES}

Baibel, B. (1989). The Bible in Tok Pisin. Port Moresby: Bible Society of Papua New Guinea.

Bickerton, D. (1977). Pidginization and creolization: language acquisition and language universals. Pidgin and Creole Linguistics, 49-67.

Bybee, J. (2003). Cognitive processes in grammaticalization. The New Psychology of Language, 2, 145-167.

Crowley, T. (1990). The position of Melanesian Pidgin in Vanuatu and Papua New Guinea. Melanesian Pidgin and Tok Pisin: Proceedings of the First International Conference on Pidgins and Creoles in Melanesia (Vol. 20, p. 1). John Benjamins Publishing.

Crystal, D. The Cambridge Encyclopedia of Language (Vol. 2). Cambridge: Cambridge University Press.

Franklin, K. J., \& Litteral, R. L. (1990). An Introductory Programmed Course in Tok Pisin; with Accompanying Tape by Stephen Thomas.

Goulden, R. J. (1989). The source of Tok Pisin structures. World Englishes, 8(2), 147-156.

Keesing, R. M. (1991). Substrates, calquing and grammaticalization in Melanesian Pidgin. Approaches to Grammaticalization, 1, 315-342.

Lefebvre, C. (2004). Issues in the Study of Pidgin and Creole Languages. John Benjamins Publishing.

Mühlhäusler, P. (1990). On the origins of the predicate marker in Tok Pisin. Melanesian Pidgin and Tok Pisin: Proceedings of the First International Conference on Pidgins and Creoles in Melanesia, 345-373.

Mühlhäusler, P., Dutton, T. E., \& Romaine, S. (2003). Tok Pisin Texts: From the Beginning to the Present. John Benjamins Publishing.

Mundhenk, N. (1990). Linguistic decisions in the Tok Pisin Bible. Melanesian Pidgin and Tok Pisin: Proceedings of the First International Conference of Pidgins and Creoles in Melanesia, 345-373.

Plag, I. (2002). On the Role of Grammaticalization in Creolization.

Roberts, S. J., \& Bresnan, J. (2008). Retained Inflectional Morphology in Pidgins: A Typological Study,

Romaine, S. (1990). Change and variation in the use of bai in young children's creolized Tok Pisin in Morobe Province. Melanesian Pidgin and Tok Pisin: Proceedings of the First International Conference of Pidgins and Creoles in Melanesia, 345-373.

Romaine, S. (1999). The grammaticalization of the proximative in Tok Pisin. Language, 322346.

Sankoff, G. (1984). Substrate and universals in the Tok Pisin verb phrase. Meaning, Form, and use in Context: Linguistic Applications, 104-119.

Sankoff, G. (1993). Focus in Tok Pisin. Focus and Grammatical Relations in Creole Languages, 117-140.

Sankoff, G., \& Brown, P. (1976). The origins of syntax in discourse: a case study of Tok Pisin relatives. Language, 631-666.

Sankoff, G., \& Mazzie, C. (1991). Determining noun phrases in Tok Pisin. Journal of Pidgin and Creole Languages, 6(1), 1-24.

Siegel, J.Tok pisin. Retrieved, 2013, Retrieved from http://www.hawaii.edu/satocenter/langnet/definitions/tokpisin.html

Thomason, S. G. (1997). A typology of contact languages. Creole Language Library, 19, 71-90. 
Tok Pisin. Retrieved, 2013, Retrieved from http://www.ethnologue.com/language/tpi Tok Pisin (2013). Encyclopedia Britannica Online.

Tung, C. (2013). Tok Pisin Language Learning Notebook. Unpublished manuscript. United States. Army Service Forces. Information, \& Education Division. (1944). Melanesian Pidgin English Language Guide USGPO.

Verhaar, J. W. (1990). Melanesian Pidgin and Tok Pisin. Proceedings of the First International Conference on Pidgins and Creoles on Melanesia.

Verhaar, J. W. (1995). Toward a Reference Grammar of Tok Pisin: An Experiment in Corpus Linguistics. University of Hawaii Press. 